DR. P. ORTEGA-BAES (Orcid ID : 0000-0002-3436-6823)

Article type : Research Paper

Handling Editor: Dr. R. Bekker

\title{
Do cacti form soil seed banks? An evaluation using species from the Southern
}

\section{Central Andes}

Lucía Lindow-López, Guadalupe Galíndez, Silvia Sühring, Valeria Pastrana-Ignes, Pablo Gorostiague, Angela Gutiérrez \& Pablo Ortega-Baes

Laboratorio de Investigaciones Botánicas (LABIBO), Facultad de Ciencias Naturales, Universidad Nacional de Salta-CONICET

Running head: Soil seed banks in cacti

Corresponding autor: Pablo Ortega-Baes. Laboratorio de Investigaciones Botánicas (LABIBO), Facultad de Ciencias Naturales, Universidad Nacional de Salta-CONICET, Av. Bolivia 5150, Salta, 4400, Argentina. e-mail: ortiga@unsa.edu.ar Tel. +54-0387-154126628.

Keywords: arid environments; Cactaceae; nurse plant; recruitment; seed germination; seed longevity; soil seed bank.

This article has been accepted for publication and undergone full peer review but has not been through the copyediting, typesetting, pagination and proofreading process, which may lead to differences between this version and the Version of Record. Please cite this article as doi: $10.1111 /$ plb. 12868

This article is protected by copyright. All rights reserved. 


\section{Abstract}

There is controversy over whether cactus species form soil seed banks. Although it is commonly assumed that cacti do not form seed banks, very few studies have evaluated them. In this work, we analyzed whether cactus species form soil seed banks, studying seed distribution, seed density and seed longevity in the Southern Central Andes. Soil samples were collected in two microhabitats (under nurse plants and in bare areas) at 12 selected sites. We determined seed presence-absence, density and distribution for 32 native cactus species. Seed longevity for six of these species was determined through a burial experiment. We recorded viable seeds for $62.5 \%$ of the 32 evaluated species, finding variation in seed density between microenvironments and among populations. In some species, the greatest seed density was found under potential nurse plants. Seed germination and seed viability decreased with burial time, with seed longevity always being less than 24 months after burial. Our results show strong evidence that cactus species do form seed banks. Seed density can vary between microenvironments and among populations, suggesting that cactus-nurse plant associations can also be explained by differential seed dispersal and not only by differential establishment. We found that Echinopsis and Gymnocalycium species form short-term seed banks. Our results will help to better understand the population dynamics of cactus species, a focal species group for conservation actions because many of them are threatened by human activities. 


\section{Introduction}

The soil seed bank (SSB) is an important stage in the plant lifespan that constitutes a persistence strategy both for annual and perennial species (Harper 1977). To know whether a plant forms a SSB, it is necessary to demonstrate that viable seeds remain in the soil for a given period of time and determine its distribution, density and longevity (Álvarez-Espino et al. 2014). The two first traits can be highly heterogeneous due to spatial-temporal fluctuations in seed production, seed dispersal and seed predation (Harper 1977; Mull \& MacMahon1996). Thus, seed density can vary significantly among populations and among the microhabitats in which the population occurs (Reichman 1984). On the other hand, seed longevity depends on morphological and physiological seed traits. In this sense, it has been indicated that the seeds of plant species that form SSBs would be characterized by 1) light requirements for germination (Pons 1992; Bowers 2000), 2) seed dormancy (e.g., the need for a post-maturation period; Murdoch \& Ellis 1992) or low germinability during seed dispersal (Bowers 2000; Baskin \& Baskin 2014) and 3) small seed size (Thompson 1993; Bowers 2000). Some of these traits, such as small seed size and light requirements, seem to be correlated (Milberg et al. 2000). Regarding seed longevity, SSBs can be classified as transient seed banks when seeds remain viable for a year or less and persistent seed banks when seeds remain viable for more than a year (Thompson 1993). When seeds remain viable in the soil for five years or less, the SSB is classified as short-term persistent seed banks, while those with seeds remaining viable for more than five years are classified as longterm persistent seed banks (Thompson 1993). 
Cacti are a diverse plant family native to arid and semiarid regions of the Americas. In these plant species, early establishment is a rare phenomenon, since very few seeds germinate, and most of the emergent seedlings do not survive the first year (Godínez-Alvarez et al. 2003). Facilitation by nurse plants is a very important factor for early establishment (Godínez-Alvarez et al. 2003; MunguíaRosas \& Sosa 2008). Nurse plants diminish the contrast between the maximum and minimum soil temperature, provide protection against predators, increase soil nutrient availability under the canopy and provide shade, which substantially reduces evapotranspiration (Godínez-Alvarez et al. 2003; Munguía-Rosas \& Sosa 2008). Even though nurse plant facilitation of cactus establishment has been widely documented, some cactus species grow associated with rocks or cavities, which facilitate seedling emergence, survival and growth (Peters et al. 2008; MunguíaRosas \& Sosa 2008).

An important aspect for understanding the dynamics of early establishment in cactus species is to know whether they form a soil seed bank (Rojas-Aréchiga \& Vázquez-Yanes 2000). The morphological and physiological traits of most of the cactus seeds (seed size and positive photoblastism) suggest that they could form soil seed banks (Bowers 2000; Rojas-Aréchiga \& Batis 2001; Flores et al. 2006, 2011; Ortega-Baes et al. 2011). In this sense, the few studies on the topic show that some cactus species do form SSBs and that they are short-term persistent seed banks (de Viana 1999; Bowers 2000, 2005; Montiel \& Montaña 2003; Cheib \& García 2012; Cano-Salgado et al. 2012; Álvarez-Espino et al. 2014). Of all the studies on SSBs in cactus species, only one has simultaneously evaluated seed distribution patterns, seed density and seed longevity (Álvarez-Espino et al. 2014). 
In this context, we evaluated whether cactus species form soil seed banks, studying seed distribution, seed density and seed longevity in northwestern Argentina. Previous studies on Argentinean cactus species (de Viana 1999; OrtegaBaes et al. 2010 b) suggest that they would produce a short-term persistent seed bank. Specifically, we address the following questions: 1) Do seeds produced in previous years remain viable in the soil until the next reproductive event? 2) Does seed density vary spatially among microenvironments (nurse plant or bare areas) and sites? and 3) What is the seed longevity in the soil? This information will allow us to determine whether cactus species form soil seed banks and what type of bank they produce.

\section{Materials and Methods}

\section{Study area}

The study was conducted in Salta province, the region with the highest cactus diversity in Argentina (Ortega-Baes et al. 2015). We selected 12 sites located in the three most diverse ecoregions for cacti in this province: Dry Chaco, High Monte and Southern Andean Yungas (Olson \& Dirnestein 2002).

\section{Seed bank}

We determined the seed distribution and density by collecting soil samples in two microhabitats (under nurse plants and in bare areas). At each site, we took, at random, 30 soil samples from each microhabitat using a cylindrical metal core (10 $\mathrm{cm}$ diameter and $3 \mathrm{~cm}$ depth). A variable number of linear transects of $100 \mathrm{~m}$ were 
established to collect the required number of samples. To determine whether seeds could remain viable in the soil for at least one year, the sampling was performed prior to the seed dispersal period. In the laboratory, we determined the volume of each soil sample and extracted the seeds using metal sieves. All the extracted seeds were identified and counted. Seed identification was carried out using a reference seed collection. We built it from seeds collected in each of studied sites. Since the aim of this study was to evaluate whether cactus species produced a soil seed bank, we did not perform a community analysis. To determine the germination capacity of the collected seeds, they were placed in Petri dishes with $1 \%$ agar and incubated in germination chambers for 30 days at $25^{\circ} \mathrm{C}$ and a photoperiod of $12 / 12 \mathrm{~h}$ light/dark. The emergence of the radicle was defined as germination. The viability of the nongerminated seeds was evaluated at the end of the assay by cutting them longitudinally and observing them with a stereoscopic microscope. Seeds were considered viable when their embryos were white and turgid (Ortega-Baes et al. 2010 b). For each species, seed abundance was determined as the number of viable seeds (germinated seeds and non-germinated viable seeds) $/ 250 \mathrm{~cm}^{3}$.

\section{Seed longevity}

Seed longevity was evaluated for only six species (Echinopsis atacamensis, E. terscheckii, E. thionantha, Gymnocalycium saglionis, G. schickendantzii and G. spegazzinii) because there were not enough seeds available for all species. During the fruiting season, we extracted seeds from ten mature fruits per species and stored them in paper bags under laboratory conditions for no longer than a week. For each species, four voile bags containing 100 seeds each were buried under woody 
species, and the same number of bags and seeds were buried in bare areas.

Selected woody species were those that showed the highest association level with cactus species in the study sites (i.e., potential nurse plants; Ortega-Baes, unpubl. data). We determined the germination proportion and seed viability of the fresh seeds, i.e., before burying them (zero burial time), and of the exhumed seeds after 6 , 12, 24 and 36 months of burial. When each burial time was reached, we extracted a bag with 100 seeds from each microenvironment (i.e., under canopy and bare area) to evaluate their germination and viability under the laboratory conditions described above. Seed viability was determined as described for the soil seed banks.

\section{Statistical analysis}

T-tests were performed to evaluate differences in seed number between canopy and bare areas. ANOVA was performed to detect differences in seed density among sites and microenvironments. We used the same analysis to evaluate the probable differences in the proportion of germinating seeds and seed viability between microenvironments and among burial times. In all analyses, the response variables (proportion of germinating seeds and seed viability) were transformed using arcsine $\sqrt{ } \mathrm{x}$. In addition, a DGC multiple means comparison test was used when the ANOVA indicated a significant difference (Di Rienzo et al. 2002). All analyses were performed using Infostat software (version 2009, Grupo InfoStat. FCA-UNC, Córdoba, Argentina). 


\section{Results}

\section{Seed bank}

Across all the sites, we recorded 32 cactus species, but only 20 of them (62.5\%) were present in the soil samples (Table 1). No seeds were recorded in the soil samples for any of the species of the subfamily Opuntioideae (Cumulopuntia boliviana, Opuntia anacantha, O. quimilo, O. schickendantzii, O. sulphurea, Quiabentia verticillata, Salmiopuntia salmiana, Tephrocactus weberi and Tunilla corrugata). The same occurred with three species of the subfamily Cactoideae (Cereus aethiops, Echinopsis thelegona and Gymnocalycium pflanzii). Ten species $(50 \%)$ presented seeds in the soil samples in more than one site, with $E$. atacamensis, E. terscheckii, G. saglionis and G. spegazzinii being the cactus species with the greatest number of sites with seeds in the soil (Table 1). The highest seed density was recorded for G. spegazzinii under canopy, at the Punilla site. Nine species presented seeds only under canopy (Table 1). Significant differences in the number of seeds between microenvironments were only recorded for E. rhodotricha, G. saglionis, G. schickendantzii and G. spegazzinii (Table 1).

No significant differences in seed density were recorded among sites or microenvironments for most of the cactus species studied. For Gymnocalycium saglionis, significant differences were only detected for the microenvironment-site interaction $(F=3.23, P=0.042)$, being higher under canopy at the Las Abritas site.For G. schickendantzii, significant differences were recorded between microenvironments $(F=4.18, P=0.043)$ and for the microenvironment-site interaction $(F=4.06, P=0.046)$. The highest seed density for this species was found under canopy at the Las Abritas site. Significant differences between 
microenvironments $(F=6.19, P=0.014)$, among sites $(F=6.15, P=0.003)$ and for their interaction $(F=6.09, P=0.003)$ were only recorded for $G$. spegazzinii. The Punilla site showed the highest seed density under canopy for G. spegazzinii. No comparisons among P. microsperma and E. albispinosa populations were performed because no seeds were found in the soil samples from bare areas (Table 1).

\section{Seed longevity}

The proportion of germinated seeds and viable seeds at zero burial time were always $\geq 0.70$ for all species. No seeds survived the 24 -month burial time. In all species, except for E. thionantha, the proportion of germinating seeds and seed viability were affected only by burial time $(P<0.05$; Fig. 1$)$. In $E$. atacamensis and $E$. terscheckii, the germination proportion significantly decreased after 12 months of burial (Fig. 1A, B). However, the seed viability for these two species significantly decreased at 6 months of burial, with a significant major decrease at 12 months of burial. This progressive decrease in seed germination and viability was also recorded for G. saglionis and G. spegazzinii (Fig. 1D, E). In G. schickendantzii, the germination proportion was higher at 6 months of burial, significantly decreasing after 12 months of burial. In this species, the seed viability decreased from 6 months of burial (Fig. 1F). In E. thionantha, microenvironment, burial time, and their interaction significantly affected the proportion of germinating seeds (microenvironment: $F=75.08, P<0.001$; burial time: $F=82.47, P<0.0001$; microenvironment-burial time interaction: $F=20.12, P<0.0001$ ) and seed viability (microenvironment: $F=13.22, P=0.019$; burial time: $F=42.11, P<0.0001$; microenvironment-burial time interaction: $F=6.75, P=0.006)$. In this species, the 
highest proportion of germinating seeds was recorded at zero burial time and in bare areas after being buried for 6 months, while the lowest proportion of germinating seeds was found under canopy. On the other hand, the highest seed viability was obtained at zero burial time and for seeds buried for 6 months (Fig. 1C).

\section{Discussion}

According to the results, $60 \%$ of the evaluated cactus species presented viable seeds in the soil samples, suggesting that some cactus species do form soil seed banks. The formation of a seed bank was previously proposed for the columnar cactus Echinopsis atacamensis (de Viana 1999) and suggested for species of the subfamily Cactoideae based on seed traits (Ortega-Baes et al. 2010 a, b). So far, only four studies have evaluated the existence of seed banks in cacti by analyzing soil samples (de Viana 1999; Cano-Salgado et al. 2012; Holland \& Molina-Freaner 2013; Álvarez-Espino et al. 2014), while other studies have only evaluated their existence experimentally (Bowers 2000, 2005; Cheib \& García 2012). According to Álvarez-Espino et al. (2014), the determination of the presence of a soil seed bank in cactus populations must be done using an integrative approach, including seed distribution, seed density and seed longevity.

A noteworthy result is that we did not find seeds of cactus species of the subfamily Opuntioideae in the soil samples, although they are conspicuous elements of arid and semiarid regions in northwest Argentina. This result was not expected since some of these species have mature fruits by the end of the summer or even in autumn-winter (e.g., Opuntia anacantha, O. quimilo and Tunilla corrugata), so the early establishment of these species can only occur during the rainy season, i.e., the 
following summer. The probable causes of this finding could be: 1) differential seed deposition patterns due to seed dispersers, 2) high level of seed predation and 3) variation in fruit production. Field observations indicate that the fruits of some species are extensively consumed by ants (e.g., O. sulphurea), which store most of the seeds in anthills. In the opuntioid cactus O. quimilo, the fruits fall to the soil by gravity, being actively consumed by tayassuids (Catagonus wagneri, Tayassu pecari and Tayassu tajacu), animals with great vagility. Future studies should evaluate whether seed dispersal affects the spatial seed distribution in opuntioid species. In desert environments, seed bank dynamics is strongly affected by seed loss due to granivory of rodents, ants and birds. For Opuntia rastrera it has been demonstrated that low seed density recorded in the soil seed bank is caused by high levels of granivory (Montiel \& Montaña 2003). We do not know, how seed predation affects seed density in the opuntioid species in Southern Central Andes arid and semiarid regions. Regarding the third cause, many cactus populations show either temporal or spatial variation or constant and extremely low fruit production. Several cactus species of the subfamily Opuntioideae recruit new individuals via asexual reproduction, such as $O$. anacantha, $O$. sulphurea, $O$. schickendantzii, Salmiopuntia salmiana and species of the Tephrocactus and Tunilla genera. It has been suggested that in clonal cacti, sexual reproduction is a rare phenomenon because they have lost their sexuality; consequently, they persist at a local scale through vegetative propagation (Ortega-Baes \& Gorostiague 2013). This could also explain the absence of seeds in the soil samples for some cactus species of the subfamily Cactoideae. In this sense, the absence of seeds of Echinopsis thelegona, a creeping columnar cactus, in soil samples could be because of a very low or null availability of seeds due to almost null fruit production. The latter seems to be a consequence of 
pollination failure since the populations of this self-incompatible species are formed by very few sexually originated individuals (Ortega-Baes \& Gorostiague 2013).

The seed densities found in the soil samples for the different studied species do not differ from those recorded for other cactus species both in Mexico (ÁlvarezEspino et al. 2014) and northwestern Argentina (de Viana 1999). According to our results, the seed density varied spatially among the cactus populations. This could be because of differential fruit production among years and populations, directly affecting the potential seed rain. In the same way, the seed distribution varied between microenvironments (i.e., under canopy and in bare areas). Seeds were found only in soil samples under the canopy of potential nurse plants or in both evaluated microenvironments. We recorded differences in seed density between the two microenvironments only for four cactus species (E. rhodotricha, G. saglionis, G. schickendantzii y G. spegazzinii), with the density always being greater under the potential nurse plants. This pattern could be a consequence of differential seed dispersal (primary and secondary seed dispersal; Álvarez-Espino et al. 2014). Through primary seed dispersal, seeds could be deposited under nurse plants when frugivores perch on them (Godínez-Alvarez et al. 2002; Álvarez-Espino et al. 2014). Secondary seed dispersal can occur by wind and streaming rain water, with nurse plants functioning as seed traps (Sánchez-Salas et al. 2012; Álvarez-Espino et al. 2014).

Cactus-nurse plant associations have proven to be a common phenomenon in the cactus family, explained by the differential early establishment in this microenvironment (Godínez-Alvarez et al. 2003; Munguía-Rosas \& Sosa 2008). Nurse plants could provide protection against predators, a greater availability of nutrients and better environmental conditions (e.g., temperature) than bare areas 
(Godínez-Alvarez et al. 2003). In this context, the greater proportion of cactus individuals associated with nurse plants recorded for species of northwestern Argentina (de Viana et al. 2001; Ortega-Baes, unpubl. data) could result from nurse plant effects. However, as our results show, cactus-nurse plant associations could also be explained by differential seed distribution due to the effects of seed dispersal agents (i.e., biotic and physical agents).

According to our results, the six studied cactus species (Echinopsis atacamensis, E. terscheckii, E. thionantha, Gymoncalycium saglionis, G. schickendantzii and G. spegazzinii) presented short-term persistent seed banks since the seeds did not survive 24 months of burial. This has been demonstrated for Stenocereus stellatus (Álvarez-Espino et al. 2014) and Ferocactus wislizeni (Bowers 2000) and has been proposed for Echinopsis atacamensis (de Viana 1999). Cactus seed mortality at two and three years of burial could have occurred through the action of pathogenic fungi, as has been described for the columnar cactus $S$. stellatus (Álvarez-Espino et al. 2014).

In all species, except for E. thionantha, seed germination and seed viability were affected only by burial time, with a significant decrease at 12 months of burial. In G. schickendantzii, the greatest seed germination was obtained at six months of burial, differing from the remaining studied species, in which the greatest seed germination was found in recently collected seeds. The results obtained for $G$. schickendantzii could be explained by post-maturity necessity for seed germination (seed primary dormancy), as proposed by Álvarez-Espino et al. (2014). 
The seed germination and seed viability of $E$. thionantha were affected by both evaluated factors (burial time and microenvironment). Both response variables significantly decreased after 12 months of burial, being significantly lower under potential nurse plants than in bare areas. These results suggest the existence of negative nurse plant effects, likely through allelopathic effects, that kill seeds and inhibit seed germination. The potential allelopathic effects of potential nurse plants on cactus establishment was previously proposed by de Viana et al. (2001), suggesting that not all plant species in a community can act as nurse plants.

In the present study, we analyzed seed distribution, seed density and seed longevity for many cactus species that are distributed in the southern Central Andes, a hotspot of cactus diversity at the global scale (Ortega-Baes et al. 2010 c, 2015). This is the first comprehensive study conducted to evaluate, at a community level, whether cactus species form soil seed banks, since most previous studies have focused on a single species (de Viana 1999; Bowers 2000; Montiel \& Montaña 2003; Cheib \& García 2012; Holland \& Molina-Freaner 2013; Álvarez-Espino et al. 2014). Our results strongly demonstrate that cactus species do form seed banks, confirming that their presence is much more common than has previously been considered in the ecological literature. As was demonstrated, seed density can vary between microenvironments and among populations. At least for six species of the Echinopsis and Gymnocalycium genera, we showed that they form short-term seed banks. Our results are very relevant for better understanding the population dynamics of cactus species since most studies (without field data support) have not considered the seed as a phase of the life cycle. Therefore, future studies should evaluate in what ways seed bank dynamics affect cactus demographic behavior. In addition, it is necessary to understand how seed banks vary spatial-temporally as a consequence of 
variations in annual seed production and how this affects the early establishment dynamics of cactus species.

\section{Acknowledgements}

The authors thank N. Frizza for assistance with the English version of the manuscript. This work was supported by CIUNSalta (Grant No. 2060), CONICET (Grant No. 01149), FONCYT (Grant No. 1492) and by a FONCYT doctoral scholarship to Lucía Lindow-López.

\section{References}

Álvarez-Espino R., Godínez-Alvarez H., de la Torre-Almaráz R. (2014) Seed banking in the columnar cactus Stenocereus stellatus: distribution, density and longevity of seeds. Seed Science Research, 24, 315-320.

Barthlott W., Hunt D. (2000) Seed-diversity in the Cactaceae: subfamily Cactoideae. Succulent Plant Research, 5, 49.

Baskin C.C., Baskin J.M. (2014) Seeds. Ecology, biogeography, and evolution of dormancy and germination. Academic Press, US.

Bowers J.E. (2000) Does Ferocactus wislizenii have a between-year seed bank? Journal of Arid Environments, 45, 197-205.

Bowers J.E. (2005) New evidence for persistent or transient seed banks in three Sonoran desert cacti. The Southwestern Naturalist, 50, 482-487. 
Cano-Salgado A., Zavala-Hurtado J.A., Orozco-Segovia A., Valverde-Valdés M.T., Pérez-Rodríguez P. (2012) Composición y abundancia del banco de semillas en una región semiárida del trópico mexicano: patrones de variación espacial y temporal. Revista Mexicana de Biodiversidad, 83, 437-446.

Cheib A.L., García Q.S. (2012) Longevity and germination ecology of seeds of endemic Cactaceae species from high-altitude sites in south-eastern Brazil. Seed Science Research, 22, 45-53.

de Viana M.L. (1999) Seed production and seed bank of Trichocereus pasacana (Cactaceae) in northwestern Argentina. Tropical Ecology, 40, 79-84.

de Viana M.L., Sühring S., Manly B.F.J. (2001) Application of randomization methods to study the association of Trichocereus pasacana (Cactaceae) with potential nurse plant. Plant Ecology, 156, 193-197.

Díaz L., Cocucci A.A. (2003) Functional gynodioecy in Opuntia quimilo (Cactaceae), a tree cactus pollinated by bees and hummingbirds. Plant Biology, 5, 1-9.

Di Rienzo J.A., Guzmán A.W., Casanoves F. (2002) A multiple-comparisons method based on the distribution of the root node distance of a binary tree. Journal of Agricultural, Biological and Environmental Statistics, 7, 129-142.

Flores J., Jurado E., Arredondo A. (2006) Effect of light on germination of seeds of Cactaceae from the Chihuahuan Desert, México. Seed Science Research, 16, 149-155.

Godínez-Alvarez H., Valiente-Banuet A., Rojas-Martínez A. (2002) The role of seed dispersers in the population dynamics of the columnar cactus Neobuxbaumia tetetzo. Ecology, 83, 2617-2629. 
Godínez-Alvarez H., Valverde T., Ortega-Baes P. (2003) Demographic trends in the Cactaceae. Botanical Review, 69, 173-203.

Harper J.L. (1977) Population biology of plants. Academic Press, UK.

Holland J.N., Molina-Freaner F. (2013) Hierarchical effects of rainfall, nurse plants, granivory and seed banks on cactus recruitment. Journal of Vegetation Science, 24, 1053-1061.

Milberg P., Andersson L., Thompson K. (2000) Large-seeded species are less dependent on light for germination than small-seeded ones. Seed Science Research, 10, 99-104.

Montiel S., Montaña C. (2003) Seed bank dynamics of the desert cactus Opuntia rastrera in two habitats from the Chihuahuan Desert. Plant Ecology, 166, 241 248.

Mull J.F., MacMahon J.A. (1996) Factors determining the spatial variability of seed densities in a shrub-steppe ecosystem: the role of harvester ants. Journal of Arid Environments, 32, 181-192.

Munguía-Rosas M.A., Sosa V.J. (2008) Nurse plant vs. nurse objects: effects of woody plants and rocky cavities on the recruitment of the Pilocereus leucocephalus columnar cactus. Annals of Botany, 101, 175-185.

Murdoch A.J., Ellis R.H. (1992) Longevity, viability and dormancy. In: Fenner, M. (ed). Seeds: the ecology of regeneration in plant communities, pp 193-229. CABI Publishing, UK. 
Olson D.M., Dinerstein E. (2002) The Global 200: Priority ecoregions for global conservation. Annals of the Missouri Botanical Garden, 89, 199-224.

Orozco-Segovia A., Márquez-Guzmán J., Sánchez-Coronado M.E., Gamboa de Buen A., Baskin J.M., Baskin C.C. (2007) Seed anatomy and water uptake in relation to seed dormancy in Opuntia tomentosa (Cactaceae, Opuntioideae). Annals of Botany, 99, 581-592.

Ortega-Baes P., Aparicio M., Galíndez G. (2010a) Vivipary in the cactus family: an evaluation of 25 species from northwestern Argentina. Journal of Arid Environments, 74, 1359-1361.

Ortega-Baes P., Aparicio-González M., Galíndez G., del Fueyo P., Sühring S., Rojas-Aréchiga M. (2010b) Are cactus growth forms related to germination responses to light? A test using Echinopsis species. Acta Oecologica, 36, 339342.

Ortega-Baes P., Sühring S., Sajama J., Sotola E., Alonso-Pedano M., Bravo S., Godínez-Alvarez H. (2010c) Chapter 8: Diversity and conservation in the cactus family. In: Ramawat, K.G. (ed.) Desert plants: biology and biotechnology, pp 157-173, Springer, Germany.

Ortega-Baes P., Godínez-Alvarez H., Sajama J., Gorostiague P., Sühring S., Galíndez G., Bravo S., López-Spahr D., Alonso-Pedano M., Lindow-López L.T., Sosa C., Curti R.N., Juárez A. (2015) La familia Cactaceae en Argentina: Patrones de diversidad y prioridades políticas para su conservación. Boletín de la Sociedad Argentina de Botánica, 50, 71-78. 
Ortega-Baes P., Gorostiague P. (2013) Extremely reduced sexual reproduction in the clonal cactus Echinopsis thelegona. Plant Systematics and Evolution, 299, 785-791.

Peters E.M., Martorell C., Ezcurra E. (2008) Nurse rocks are more important than nurse plants in determining the distribution and establishment of globose cacti (Mammillaria) in the Tehuacán Valley, Mexico. Journal of Arid Environments, 72, 593-601.

Pons T.L. (1992) Seed responses to light. In: Fenner, M. (ed.). Seeds: the ecology of regeneration in plant communities. CABI Publishing, UK.

Reichman O.J. (1984). Spatial and temporal variation of seed distribution in Sonoran Desert soils. Journal of Biogeography, 11, 1-11.

Rojas-Aréchiga M., Batis A. (2001) Las semillas de cactáceas ... ¿forman bancos en el suelo? Cactáceas y Suculentas Mexicanas, 46, 76-82.

Rojas-Aréchiga M., Vázquez- Yanes C. (2000) Cactus seed germination: a review. Journal of Arid Environments, 44; 85-104.

Sánchez-Salas J., Jurado E., Flores J., Estrada-Castillón E., Muro-Péreza G. (2012) Desert species adapted for dispersal and germination during floods: experimental evidence in two Astrophytum species (Cactaceae). Flora, 207, 707-711.

Schupp E.W. (1995) Seed-seedling conflicts, habitat choice and patterns of plant recruitment. American Journal of Botany, 82, 399-409. 
Thompson K. (1993) Persistence in soil. In: Hendry, G.A.F. \& Grime, J.P. (eds). Methods in comparative plant ecology, a laboratory manual, pp 199-202. Chapman and Hall, UK.

\section{Captions}

Table 1. Number of viable seeds (mean \pm SD) in soil samples $\left(250 \mathrm{~cm}^{3}\right)$ for each site, species and microenvironment. Different letters indicate significant differences between under canopy and bare areas for each species $(P<0.05)$.

Figure 1. Seed germination $(\square)$ and seed viability $(\square)$ (mean \pm EE) at different burial times (0, 6 and 12 months) in each of the microenvironments (under canopy and bare areas) for Echinopsis atacamensis (A), E. terscheckii (B), E. thionantha (C), Gymnocalycium saglionis (D), G. spegazzinii (E), and G. schickendantzii (F). Different letters indicate significant differences $(P<0.05)$. 


\section{Supporting information}

Table S1. Cactus species registered in the studied sites. Taxonomy follows Hunt (2006). 
Table 1. Number of viable seeds (mean \pm SD) in soil samples $\left(250 \mathrm{~cm}^{3}\right)$ for each site, species and microenvironment. Different letters indicate significant differences between under canopy and bare areas for each species $(P<0.05)$.

\begin{tabular}{|c|c|c|c|}
\hline Site & Species & Under canopy & Bare areas \\
\hline La Pedrera & Echinopsis terscheckii & $1.1 \pm 3.38^{\mathrm{A}}$ & $0.56 \pm 2.11^{\mathrm{A}}$ \\
\hline \multirow[t]{3}{*}{ El Galpón } & E. rhodotricha & $1.09 \pm 2.42^{\mathrm{A}}$ & $0.09 \pm 0.52^{\mathrm{B}}$ \\
\hline & E. albispinosa & $0.84 \pm 1.97$ & 0 \\
\hline & Cleistocactus baumannii & $0.76 \pm 2.18$ & 0 \\
\hline \multirow[t]{7}{*}{ Peñas Azules } & E. albispinosa & $1.38 \pm 2.84^{\mathrm{A}}$ & $0.46 \pm 1.55^{\mathrm{A}}$ \\
\hline & E. terscheckii & $1.84 \pm 3.95^{\mathrm{A}}$ & $0.7 \pm 1.82^{\mathrm{A}}$ \\
\hline & Gymnocalycium saglionis & $0.64 \pm 1.51^{\mathrm{A}}$ & $0.57 \pm 1.71^{\mathrm{A}}$ \\
\hline & G. schickendantzii & $0.56 \pm 1.32^{\mathrm{A}}$ & $0.55 \pm 1.81^{\mathrm{A}}$ \\
\hline & C. baumannii & $1.65 \pm 3.64^{\mathrm{A}}$ & $0.38 \pm 1.19^{\mathrm{A}}$ \\
\hline & C. hankeanus & $1.32 \pm 3.21^{\mathrm{A}}$ & $0.47 \pm 1.47^{\mathrm{A}}$ \\
\hline & Harrisia pomanensis & $0.45 \pm 1.44^{\mathrm{A}}$ & $0.1 \pm 0.57^{\mathrm{A}}$ \\
\hline \multirow[t]{3}{*}{ El Algarrobal } & Stetsonia coryne & $0.22 \pm 0.47^{\mathrm{A}}$ & $0.41 \pm 0.8^{\mathrm{A}}$ \\
\hline & E. rhodotricha & $1.4 \pm 4.87^{\mathrm{A}}$ & $0.35 \pm 0.84^{\mathrm{A}}$ \\
\hline & C. smaragdiflorus & $0.68 \pm 1.65^{\mathrm{A}}$ & $0.14 \pm 0.44^{\mathrm{A}}$ \\
\hline \multirow[t]{2}{*}{ Casa de Piedra } & E. terscheckii & $0.6 \pm 1.43^{\mathrm{A}}$ & $0.76 \pm 3.21^{\mathrm{A}}$ \\
\hline & C. baumannii & $0.43 \pm 1.15^{\mathrm{A}}$ & $0.33 \pm 1.27^{\mathrm{A}}$ \\
\hline
\end{tabular}




\begin{tabular}{|c|c|c|c|}
\hline & C. smaragdiflorus & $1 \pm 3.71^{\mathrm{A}}$ & $0.71 \pm 2.27^{\mathrm{A}}$ \\
\hline & G. saglionis & $1.24 \pm 3.61$ & 0 \\
\hline & G. schickendantzii & $0.72 \pm 2.51$ & 0 \\
\hline & Parodia microsperma & $0.74 \pm 2.14^{\mathrm{A}}$ & $0.21 \pm 1.14^{\mathrm{A}}$ \\
\hline Sunchales & E. ancistrophora & $1.98 \pm 6.35$ & $0.49 \pm 1.69$ \\
\hline & E. terscheckii & $2.88 \pm 9.23$ & $0.36 \pm 1.15$ \\
\hline Las Abritas & G. saglionis & $1.88 \pm 3.83^{\mathrm{A}}$ & $0.21 \pm 0.84^{\mathrm{B}}$ \\
\hline & G. schickendantzii & $2.22 \pm 3.81^{\mathrm{A}}$ & $0.29 \pm 0.91^{\mathrm{B}}$ \\
\hline & E. aurea & $1.8 \pm 3.65^{\mathrm{A}}$ & $0.61 \pm 2.37^{\mathrm{A}}$ \\
\hline Punilla & E. leucantha & $0.68 \pm 1.81$ & 0 \\
\hline & E. atacamensis & $0.35 \pm 1.34^{\mathrm{A}}$ & $0.38 \pm 1.01^{\mathrm{A}}$ \\
\hline & G. spegazzinii & $18.35 \pm 39.44^{\mathrm{A}}$ & $0.46 \pm 1.27^{\mathrm{B}}$ \\
\hline & P. microsperma & $0.4 \pm 1.41$ & 0 \\
\hline Seclantás 1 & E. atacamensis & $1.18 \pm 4.62^{\mathrm{A}}$ & $0.17 \pm 0.91^{\mathrm{A}}$ \\
\hline & G. spegazzinii & $0.44 \pm 1.41^{\mathrm{A}}$ & $0.6 \pm 2.36^{\mathrm{A}}$ \\
\hline Los Cardones & E. haemathantha & $0.4 \pm 1.24$ & 0 \\
\hline & E. atacamensis & $0.55 \pm 2.04$ & 0 \\
\hline & Denmoza rhodacantha & $0.31 \pm 1.24$ & 0 \\
\hline Seclantás 2 & E. atacamensis & $0.97 \pm 2.76$ & 0 \\
\hline
\end{tabular}




\begin{tabular}{|c|c|c|}
\hline E. thionantha & $0.28 \pm 1.06^{\mathrm{A}}$ & $0.36 \pm 1.13^{\mathrm{A}}$ \\
\hline P. aureicentra & $0.17 \pm 0.63^{\mathrm{A}}$ & $0.2 \pm 0.78^{\mathrm{A}}$ \\
\hline G. spegazzinii & $0.49 \pm 1.87^{\mathrm{A}}$ & $0.23 \pm 0.9^{\mathrm{A}}$ \\
\hline G. saglionis & $0.54 \pm 1.3^{\mathrm{A}}$ & $0.68 \pm 2.29^{\mathrm{A}}$ \\
\hline G. spegazzinii & $0.55 \pm 1.58$ & 0 \\
\hline E. atacamensis & $0.37 \pm 1.17^{\mathrm{A}}$ & $0.46 \pm 1.52^{\mathrm{A}}$ \\
\hline
\end{tabular}

This article is protected by copyright. All rights reserved. 
A

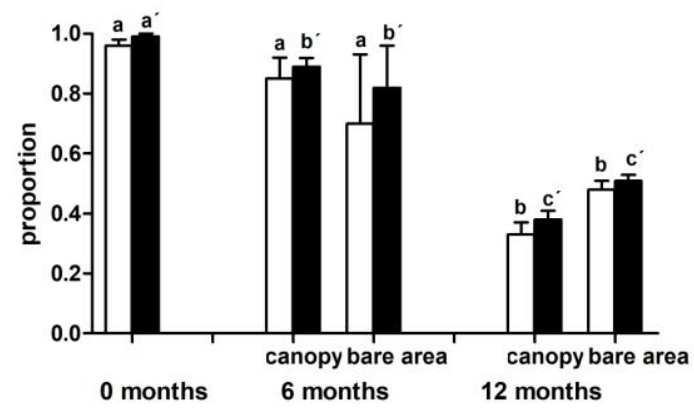

C

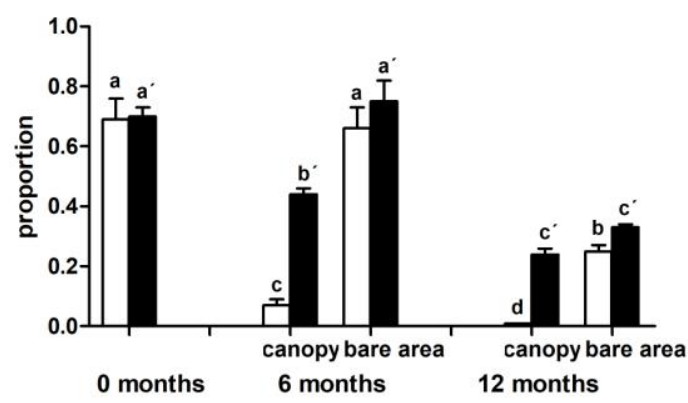

E

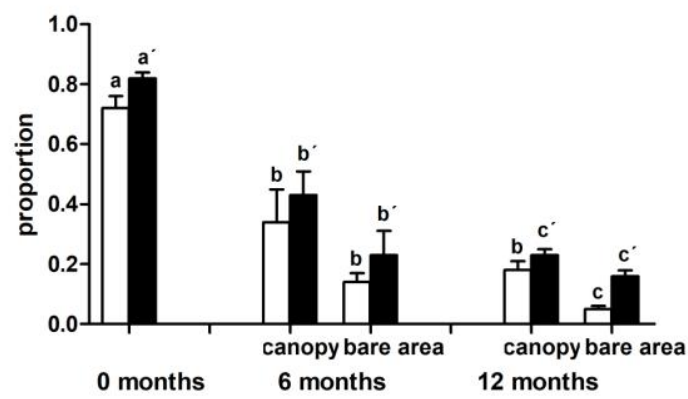

B

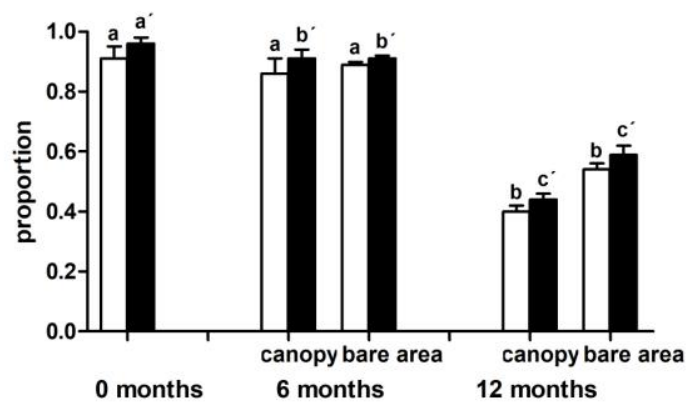

D

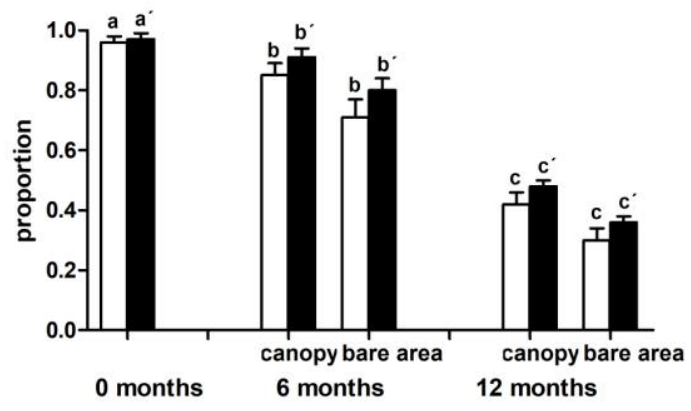

$\mathbf{F}$

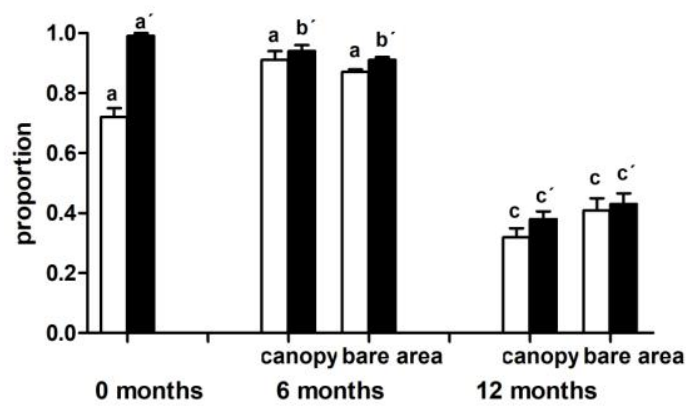

